\title{
UNIONS, HOUSING COSTS, AND THE NATIONAL LABOR POLICY
}

\author{
Sylvester Petro*
}

\section{INTRODUCTION}

The more one observes the housing industry the more remarkable it seems that there is as much activity as there is, that so many homes are built each year within the reach of persons of modest income, that the houses stand as sturdily as they do, or that they are as comfortable as they are. For no comparable industry is bound as tightly and in as many ways. There are village, town, county, and state boards of various kinds which more often than not impose unnecessary costs and thus tend to put a damper upon building. In larger communities, the village boards expand into multifarious bureaucracies whose regulations and idiosyncracies must be countered in one way or another by the person intent upon filling a piece of empty land with a home or apartment building or other structure. The buyer has his own ideas about what he wants, and when he enters the market for a home he usually prefers something other than a mass-produced edifice as indistinguishable as one among the millions of Chevies which roam the streets.

The tradesmen account by themselves for a number of restrictions. Combine theirs with those of government bureaucracies and the rigidities multiply and expand. Plumbers and electricians and a number of other trades have their unions; they are also licensed trades, licensed by government. Unionization alone, at least in the building industry, involves a significant spectrum of productivity limitations and probably unnecessary cost-increments. Unionization plus governmental licensing strengthens control of labor supply and thus enhances the capacity of building tradesmen and their unions to raise costs above the levels they would reach in genuinely free markets where access is unrestrained.

Any overall study of the factors inhibiting the construction industry and unnecessarily raising its costs must take note, not only of all these influences, but also of the probability that not all the inhibitory, cost-raising elements either can or should be eliminated. In an ideal world without restraints it is possible at least to conceive of houses built in the way that automobiles are now being built, on massproduction lines. One may doubt, however, whether such housing would have the appeal of the kind of housing we are accustomed to, or that it will ever be possible to dispense entirely with town planners, zoning boards, and materials codes.

A.B. 1943, J.D. 1945, University of Chicago; LL.M. 1950, University of Michigan. Professor of Law, New York University. Member of the Illinois bar. Author, The Labor Policy of the Free Society (1957), The Kohler Strike (1961), The Kingsport Strike (1967). Contributor of labor relations articles to New York University Annual Survey of American Law and to numerous legal and general periodicals. 
Recognizing that there are limitations to the economies which may be introduced into home construction does not mean that all is well, or even that all is as well as reasonably can be expected. On the contrary, it seems obvious that improvements in the form of removal or reduction of arbitrary and irrational restrictions are possible all along the line. This seems true at least of the aspects of the construction industry with which this article deals.

No one can be sure of the amount which they add to construction costs, but restrictive union practices certainly add something. Moreover, any coercively imposed restriction is from a social point of view both unnecessary and undesirable. A union which prevents nonunion men from practicing a construction trade is getting in the way of the development of the good society; whether the victim is white or black makes not a great deal of difference, for in either case a personal injustice is being done and the cost and therefore the availability of housing are being prejudiced. The conclusion must be the same in regard to the obstacles which unions coercively erect against the introduction of cost-reducing technological advances in home building. Here also the social cost, whatever it may be, is too high.

I do not intend in this article to deal with all the ways in which unions affect construction costs or even with all the forms of restrictionism which they practice. My intention is, first, to sketch generally the economic framework within which unions operate in the construction industry. Then I shall outline the ways in which unions alone, unaided by such controls as licensing laws, seek to gain and maintain control of the labor supply and costs in the industry. Finally, the major portion of the article will explain how the national labor policy as developed by Congress, the National Labor Relations Board, and the Supreme Court is in some ways checking and in other ways encouraging restrictive union practices in construction.

\section{I}

Economic Framework of the Construction Industry

When President Lyndon B. Johnson made his Economic Report to the nation on January 26, I967, according to The New York Times, he "tacitly abandoned . . . the Government's fixed standard of 3.2 per cent for noninflationary wage increases, approving settlements somewhat higher." .The Wall Street Journal indicated that increases gained by the construction unions had steadily exceeded the "Guideposts," that the President's Council of Economic Advisers considered those increases (averaging more than five per cent annually) "inflationary," and that the President's counsel of moderation was addressed as much to the construction unions as to any other group. ${ }^{2}$

Notwithstanding the pleas for restraint, however, wage settlements in the construc-

\footnotetext{
${ }^{1}$ N.Y. Times, Jan. $27, \mathrm{xg67}$, at I, col. 8.

2 Wall Street Journal, Jan. 27, 1967, at 4, cols. 2-3.
} 
tion industry during 1967 have been the highest on record. Victor Riesel reported in his column of May 31, I967, that bulldozer operators represented by the International Union of Operating Engineers were on strike in Ohio "in a bid for wage hikes which would bring them $\$ 500$ a week, inclusive of normal overtime pay."3 Explaining further, Mr. Riesel said: ${ }^{4}$

The union's "request" was for a pay raise of $\$ 92$ a week for straight time and $\$ 121.70$ a week with routine overtime. This did not include penalty time, or hazard time or special holiday overtime which sometimes develops when a contractor drives to meet his deadline after acts-of-God delays or, as in this case, the acts of some mighty men. . . . It appears that the Ohio Local . . . is asking for an average of from 46 to 55 percent increase over the current base pay.

While few were as ambitious as the Ohio bulldozer operators, the Bureau of National Affairs reported that construction unions had negotiated in the first half of 1967 average increases of thirty-three cents per hour, more than double the allindustry average of 13.7 cents per hour, and the highest since the Bureau had begun its surveys of wage settlements in $1949 .^{5}$ In discussions with homebuilders in Westchester County, New York, I was told repeatedly that wage raises negotiated there would by themselves require price increases of from $\$ 500$ to $\$ 1000$ on each home built this year.

In technologically progressive industries, the price-effects of substantial wage increases are softened, if not completely absorbed, by labor-saving machinery, new methods of production, and other cost-reducing devices. The construction industry, however, is apparently reconciled to a constant process of adding increased labor costs immediately to price, even when the demand for housing falls. One columnist, ${ }^{6}$ writing in the Spring of $x 967$, urged prospective homeowners to "buy now," since, she felt, the wage increases recently negotiated by the building trades unions, often extending over three-year periods, could not help boosting housing prices in the years to come. She said: "Even during the worst of the construction slump in Ig66, construction cost rose. Homebuilders are openly saying that home prices in Ig67 will be at least 5 per cent higher than in I966, and some put the rise at io per cent."7

If the building trades unions continue to gain in the future the relatively high wage increases that they have gained in the past, and if those increases are not balanced by increased productivity, housing costs may well climb out of reach of the mass market, perhaps completely out of sight. The result would be a recurrence of the phenomena which have characterized the construction industry so often in the

\footnotetext{
${ }^{3}$ Citizen Register (Ossining, N.Y.), May 3I, I967, at II, col. I.

'Id.

${ }^{8}$ Citizen Register (Ossining, N.Y.), July 21, 1967 , at 19 , cols. 5-8.

- Miss Sylviz Porter, id.

IId.
} 
past-a falling off of effective demand, leading to a worsening of present housing conditions and to underemployment, not only in the construction industry, but in all the many areas of the economy which prosper when construction activity is high.

U.S. Senator Abraham A. Ribicoff (of Connecticut) was undoubtedly preoccupied with these possibilities when, early in 1967 , he urged the Senate to act boldly on construction problems, especially in urban areas. ${ }^{8}$ Among other things, he advocated a ten-year, \$50-billion plan to eliminate and rebuild what he estimates at 4.5 million "substandard" housing units that now exist in the nation's metropolitan areas. He also proposed an "institute for urban development" to examine ways of reducing the costs of housing by improving construction technology. ${ }^{0}$

The problem is evident. Both national housing policies and personal desires for improved housing require that something be done about construction costs and prices. It is vain to look for miracles. The law of costs applies as rigorously in the construction industry-and to government or social objectives-as it does everywhere else. Either labor costs are going to have to be checked, or cost-reducing technologies are going to have to be developed and introduced on a large scale into homebuilding as means of keeping increased labor costs from pushing the price of housing out of reach. These are the implications of Senator Ribicoff's recommendations, as they are, indeed, of any serious consideration of current events in the construction industry.

Not long after Senator Ribicoff's speech, however, the Supreme Court of the United States handed down a decision which is likely to lead to the frustration of many technological developments in the construction industry. In the National Woodwork Manufacturers Association case, ${ }^{10}$ five of the nine Justices took the position that a union had the right to bargain for, and to strike to enforce, a rule against the use of prefinished or pre-assembled products on a construction job. I shall be dealing in detail with this decision later on. Here it is necessary to observe only that generally applauded housing goals are scarcely likely to be realized unless something is done about the ancient Luddite dread of advancing technology-a dread which I intend to demonstrate probably figured much more largely than did legal analysis in the majority opinion in the National Woodwork case.

\section{II}

\section{Union Control of Labor and Costs}

It seems desirable before going into legal analysis to set forth as simply as possible the patterns of conduct and the economic devices which the construction trades unions have developed over the years as means of raising labor costs or prices in the building

\footnotetext{
${ }^{8}$ N.Y. Times, Jan. $24, \mathrm{I} 967$, at $\mathrm{x}$, col. 8.

- Id.

${ }^{10}$ National Woodwork Mfrs. Ass'n v. NLRB, 386 U.S. 612 (1967).
} 
industry. Such an exposition will put our subject in its most relevant context. That context is classic monopoly analysis. ${ }^{11}$

Insofar as it creates a social problem, monopoly must always involve one or another kind of abusive or coercive restriction of alternative sources of supply of the good or service in question. Michelangelo was in a class by himself as a sculptor, and he "monopolized" his own services as such. So long, however, as he refrained from preventing other sculptors from carving he could scarcely be thought of as posing a "monopoly problem" for society. People were free to seek the services of other sculptors without fear of reprisals or of harm from him.

The monopolist who creates a social problem is not content to allow free intercourse between those who demand and others who supply goods or services of the general kind which he supplies. He will probably go for help first to government, the most powerful agency of society, for government is physically capable of barring competition to a degree unequalled by any private agency. Moreover, contrary to frequently heard protestations, governments have historically been friendly to monopoly, and the government of the United States has been in recent years no exception to this historical rule. ${ }^{12}$ Thus it is not surprising that the building trades unions, along with others (for example, the maritime unions), have resorted frequently to government as a means of ousting or limiting competition from both nonunion construction workers and competitive products. I refer here to such governmental measures as licensing laws, building codes, and wage determinations under public contracts laws.

Our concern here, however, is with private, nongovernmental practices aimed at eliminating competition from nonunion workers or from products which, by reducing labor costs, are competitive in exactly the same sense, economically, as lower-cost nonunion labor. These practices, which may be called "market controls" for lack of a better term, divide conveniently (though not distinctly) into two categories-namely "predatory practices" (borrowing from the antitrust literature) and "contractual restrictions."

\section{A. Predatory Practices}

By predatory practices I mean those coercive or near-coercive activities by means of which the construction unions, along with most other unions, make it physically or economically painful for nonunion labor to compete for jobs, or for builders and contractors to engage or to retain competitive labor. The extreme form of this type of monopolistic restriction is physical violence. A union may assault nonunion workers or sabotage a construction project employing such workers. ${ }^{13}$ When it

\footnotetext{
${ }^{11}$ See generally L. Von Mises, Human Action 354-76 (rst ed. 1949), for the most definitive monopoly analysis that I have ever encountered, and the one followed in this article.

${ }^{12}$ See W. Adams \& H. Gray, Monopoly in America: The Government as Promoter (1955).

${ }^{13}$ See Gulf Coast Bldg. \& Constr. Trades Council v. F. R. Hoar \& Son, Inc., 370 F.2d 746 (5th Cir. I967).
} 
eliminates competition in this fashion, the monopolization is almost as effective as it is when the supremely powerful paraphernalia of government are bent upon denying the public the benefits of competition.

A union may seek to control labor supply and costs less drastically by the activity known as "peaceful stranger picketing." For example, if a carpenter subcontractor employs nonunion men, the Brotherhood of Carpenters may employ one or more persons to patrol the construction project, usually with placards which may say as little as "The Carpenters on This Job are Nonunion Men," or as much as "This Project Is Unfair to Organized Labor; Union Workers Take Note; LABOR SOLIDARITY FOREVER!"14

As a general rule, such picketing will tend at least to embarrass operations at the construction site; often it will halt all operations. The Teamsters members who deliver construction materials may refuse to cross the picket line; or members of other construction trades unions employed on the project may refuse to work behind the picket line. In consequence, the builder or the general contractor who has engaged the nonunion carpentry subcontractor is likely to have second thoughts. He may put pressure on the latter to replace his nonunion men with members of the picketing Carpenters, or he may replace him with a unionized carpentry subcontractor. ${ }^{15}$ In either case, the nonunion labor will have been ousted, and the Brotherhood of Carpenters will have effectively carried through a monopolistic, competition-excluding operation.

The same result may be and often is produced without picketing. As a member of the local building and construction joint trades council, the Brotherhood of Carpenters may get in touch directly with the appropriate officials of other unions whose members are working on the offending project. This direct contact may, through various channels in each union, possibly with varying degrees of effectiveness, cause either total or fragmentary work stoppages. ${ }^{16}$ Similar pressures, leading to similar results, may be imposed in a number of other ways-for example, by means of blacklists or propaganda campaigns addressed to architects, builders, and prospective owners, exhorting them to refrain from dealing with nonunion contractors. Sometimes these campaigns are purly hortatory; at other times, the union will threaten to boycott in turn all who refuse to respond favorably. ${ }^{17}$

There is, of course, a material distinction between the physically violent methods of excluding nonunion labor, on the one hand, and the peaceful picketing, the voluntary cooperation among unions all belonging to the same trades council, and the blacklisting, on the other. The latter contain a consensual element absent in the former. Even when a union pipefitter respects the Carpenters' picket-line because he knows

\footnotetext{
${ }^{14}$ See Rommel-McFerran Co. v. Local 369, IBEW, 36r F.2d 658 (6th Cir. 1966).

${ }^{26} I d$.

${ }^{10}$ See Building \& Constr. Trades Council of Tampa, 132 N.L.R.B. 1564 (196r).

${ }^{17}$ The classic case was Bossert v. Dhuy, 221 N.Y. 342 , II7 N.E. 582 (I917).
} 
that he will be fined by his own union if he crosses it, there is a consensual foundation for his conduct. The fine will normally be based upon provisions in the union constitution or bylaws. Common law theory holds that union membership is a contractual relationship, with the terms of the contract set out in the union constitution and by-laws. ${ }^{18}$ If those documents impose a duty upon members to refuse to work on picketed projects, or when so instructed by duly authorized union officials, it is the worker's own membership contract which requires him to quit working, not an external coercive influence. He has agreed to abide by his union's rules. ${ }^{19}$

The analysis is admittedly somewhat attenuated. The pipefitter may himself have joined the union only because, owing to the largely prevalent closed-shop conditions of the construction industry, he could not otherwise have gained employment as a pipefitter. Perhaps, indeed, he joined the union originally under a threat of physical violence. Or perhaps economically and physically coercive activities were inextricably intermingled in the long and complex history of his union's rise to power in the construction industry. For my own part, I consider the latter to be the most generally accurate explanation of the closed-shop conditions which prevail in the building industry.

Difficult or impossible as it may be to disentangle the roles played by physical violence and economic coercion, it will not do to disregard the distinction between them. Our traditions, our legal and economic principles, even our morals have long been shaped and directed along lines based upon the idea that physical violence is unequivocally unacceptable, whereas economic coercion may be tolerated in some cases and forbidden in others. There is a constraining element in almost all contracts; when it becomes strong enough to be called "duress" we sometimes hold that it invalidates the contract. But while the principle is there, the application has always been tricky. ${ }^{20}$ As we shall see, this long-run uncertainty with respect to the social acceptability of economically coercive activities probably has more to do with the confusion of present labor relations law than any other single factor.

Although there are many other "predatory" practices, they are all extensions of the kinds we have covered. Thus, if the Carpenters refuse to work on a building because lumber supplies are coming from a nonunion mill, the competition of the nonunion millworkers is as much the target of the union's action as the more direct competition of the nonunion carpenters was in the case we have been considering. There is a tendency to designate a strike against the use of nonunion-made goods as a "product boycott." But whatever it may be called, it is the same case of union labor against nonunion labor that we have been considering all along. Here as there, the Carpenters Brotherhood is pursuing the normal monopolistic objective: exclusion of competition. To say that the case differs because the union carpenters are "only

\footnotetext{
${ }^{28}$ Cf. Mayer v. Journeymen Stone-Cutters' Ass'n; 47 N.J. Eq. 519, 20 A. 492 (Ch. I890).

10 Cf. NLRB v. Allis-Chalmers Mfg. Co., 388 U.S. I75 (1967).

${ }^{20} \mathrm{Cf}$. Henningsen v. Bloomfield Motors, Inc., 32 N.J. 358, 16r A.2d 69 (rg60).
} 
exercising the right to engage in a primary strike" does not establish much of a distinction. In all these cases the men who refuse to work are exercising what might equally be called a "right to strike." The pipefitter who refuses to work on a job employing nonunion carpenters reflects his own union's conception of where the interests of pipefitters lie. It would be extremely difficult to prove that the competitive effects differ from the one type of competition-ousting work stoppage to the other. If competition is being inhibited in the one, it is being no less inhibited in the other. Once the long step of prohibiting peacefully-conducted boycotts or strikes has been taken, any "line-drawing" among them has to be arbitrary-more so in some cases, less so in others, but still arbitrary in all, from the point of view of competitive effects.

Unionized carpenters may refuse to work because they object to the use of certain products incorporating steps in production which have in the past been done at the construction site. Pre-hung doors present a current example. ${ }^{21}$ Historically the process of installing doors in a building has involved a number of constructionsite operations, such as cutting the door to size, drilling for handles, fitting hinges, installing the jambs, and so on. Today entirely assembled door-units are available, so that carpenters at the jobsite need only insert the assembled unit between the roughedin studs. With hourly labor rates as high as they have become, contractors naturally look with interest upon such means of reducing the time of journeymen carpenters on the job. We see here a classic example of the labor-cost-saving technological development, precisely the kind of development which would make it possible to pay construction carpenters higher hourly wages without raising the price of housing beyond the reach of consumers.

If the unionized carpenters refuse to install such pre-fitted doors, is their conduct any different in nature or effect from picketing a project which employs nonunion carpenters? Does it make a difference that the refusal to install pre-fitted doors applies as well to those assembled by union labor as to those assembled by nonunion labor? From the economic point of view it is extremely difficult to identify any significant distinction. The purpose is in any case to eliminate the competition offered by other men seeking to serve the same consumer demand or to fulfill the same productive function. As the consumers' mandatary, ${ }^{22}$ directly or indirectly, the contractor who orders the pre-fitted doors, like the contractor who employs nonunion labor, does so because in one way or another he expects his labor costs to be reduced. It must be emphasized that the contractor is interested in total labor costs, which bear no necessary relationship to wage rates. Indeed total labor costs may be lower where higher hourly wage rates are paid; conversely total labor costs may be higher

\footnotetext{
${ }^{21}$ This was the case in National Woodwork Mfrs. Ass'n v. NLRB, 386 U.S. 612 (1967).

${ }^{22}$ See generally on the employer as agent for consumers, and on trade unions as organizations likely to abuse both society and nonunion workers, the dissenting opinion of Holmes, C.J., in Plant v. Woods, 176 Mass. 492, 504, 57 N.E. IOII, I015 (1900).
} 
where wage rates are lower. It is a question of how much production the contractor gets out of each hour's work.

Paradoxically, then, the unionized carpenters at the construction site may refuse to install pre-fitted doors even though the factory work involved in pre-fitting the doors was paid at an hourly rate equal to or even higher than that paid to the constructionsite carpenters. But from the point of view of economics, which is to say from the point of view of society and of the consumer, the strike must nevertheless be considered an anticompetitive, cost-raising operation. Moreover, it is anticompetitive and cost-raising in precisely the same way as the other cases we have been considering.

Finally, from the point of view of the striking carpenters themselves their activity may be considered harmful. If the boycott of pre-fitted doors is allowed, and if it works, so too then must other such boycotts be allowed, with the result that the introduction of cost-saving technological developments will be hampered generally. The further consequence must be higher prices for housing and therefore less construction activity and less work for the unionized carpenters themselves.

Thus, it seems accurate to say that "work-preservation" product boycotts and boycotts more directly addressed to the elimination of competitive workers analyze out as substantially identical forms of conduct, regardless of the particular means (assuming only that the means are peaceful) used to effectuate them. Whether the means take the form of picketing, blacklisting, or a direct verbal request for a work stoppage or other kind of refusal to deal, on the one hand; or whether on the other it be a direct work stoppage in the form of a refusal, for example, to install pre-assembled products-in any case, economic pressure is exerted in order to discourage resort to competitive labor. In short, all the "predatory practices" typical of the construction trades unions, with the exception of violent conduct, are mere varieties of the same general species of action, with only insignificant distinctions among them. They all say, in effect: "If you deal with a competitor you will have to do without our services and without the services of unions, contractors, architects, and others who will cooperate with us in denying you their services, too."

\section{B. Contractual Restrictions}

By "contractual restrictions" I mean those provisions in collective agreements with either single employers or groups of employers which place a duty upon the employers (a) to insist upon union membership as a condition of employment, or (b) to deal only with other employers approved by the contracting union, or (c) to refrain from specifying products to which the contracting union is opposed. It will be seen immediately that such "contractual restrictions" are the "predatory practices" of the construction unions agreed to in advance.

Thus the agreement requiring union membership as a condition of employment -sometimes referred to as a "union-security" agreement and sometimes as a "com- 
pulsory-unionism" agreement-insures in advance that only union members will be employed; or that, if a nonunion man is hired, he will be required to join the union within a specified period if he wishes to be retained. If such an agreement is induced by a strike, a threatened strike, a picket-line, a boycott, or, above all, by violence, its kinship with the "predatory practices" may be seen quickly. Since virtually all compulsory-unionism agreements are induced in one or another such way, there is little practical point in discussing them further. They are monopolistic, competitionexcluding devices in precisely the sense in which predatory practices are, to much the same degree, and subject to the same difficult line-drawing problems that exist whenever an attempt is made to limit peaceful, consensual activities which contain elements of economic coercion.

Agreements requiring the contracting employer to refrain from dealing with certain other employers-often called "hot-cargo" agreements-again rest upon the interest of the contracting union in eliminating cost-reducing competition. More often than not, probably, the target of the "hot-cargo" agreement is a class of firms which the contracting union has tried unsuccessfully to "organize." Failing to organize such firms and thus to control (that is, usually, to raise) their labor costs, the union seeks to eliminate them. A classic example is presented by the Carpenters' drive, now well over a half-century old, to compel lumber mills all over the country to employ only members of the Carpenters Brotherhood. ${ }^{23}$

A variety of the "hot-cargo" contract sometimes referred to as a "product-boycott" calls for somewhat more discussion. In the well-known Allen Bradley case, ${ }^{24}$ Local 3 of the International Brotherhood of Electrical Workers (IBEW) joined with New York City manufacturers of electrical products and contractors installing such products to prevent the use there of electrical products manufactured elsewhere, even when manufactured by firms employing members of other IBEW local unions. There is no apparent method by means of which the New York City manufacturers, acting alone, could have excluded the competitive products. But if IBEW Local 3 agreed to refuse to allow its members to install them, the exclusion could be accomplished, since, by one means or another, Local 3 had established closed-shop, monopoly control electrical installation in the city. Representing both construction electricians and employees of the electrical products manufacturers, IBEW Local 3 considered it advantageous to restrict the competition offered even by members of other IBEW locals, for doing so would provide more demand for the services of its own members and in all probability higher pay. Hence IBEW Local 3 agreed with both the manufacturers association and the contractors association to boycott electrical products not manufactured in New York City.

The Lumber Products Association case ${ }^{25}$ revealed an identical concert of objectives

\footnotetext{
${ }^{23}$ See Bossert v. Dhuy, 221 N.Y. 342, II7 N.E. 582 (1917).

24 Allen Bradley Co. v. Local 3, IBEW, 325 U.S. 797 (r945).

${ }^{25}$ Lumber Products Ass'n v. United States, 444 F.2d 546 (9th Cir. 1944).
} 
and action among millwork producers, construction contractors, and the Brotherhood of Carpenters in the San Francisco area. There the Carpenters agreed to refuse to work with lower-cost lumber products coming from Washington, Oregon, and Wisconsin-where, unlike San Francisco, millwork was produced on a large-scale, rationally-organized, low-cost basis.

The law reports reveal similar arrangements among manufacturers, contractors, and building trades unions in most of the other segments of the construction industry. ${ }^{26}$ The basic requirements seem to be closed-shop control by the union involved and a municipality or other geographical area which yields readily to $a$ monopolistic type of enclosure. Political connivance is probably highly important, but the operating mechanism is the union's ability to control all installation of the products in question.

\section{Monopoly and the Public Interest}

Reviewing the broad spectrum of monopolistic or competition-excluding activities of the construction unions which I have outlined, we may observe that the one feature common to all is the attempt to gain for members of the union involved control of labor functions for which other workers, union and nonunion, are willing to compete. Seeking to gain higher returns for their members, the construction. unions know that they must control supply if they are to be successful. They may control supply directly by excluding competitive workers, or indirectly by excluding the products of competitive workers.

To view the situation as one involving a conflict between "labor and capital" or "management and unions" is to misunderstand it. The conflict is between workers, not only fundamentally, but virtually exclusively, with specifically employer-interestsinvolved only marginally and tangentially. From the point of view of the publie interest, the basic questions to be asked in formulating legal policy are: How far shall unions be allowed to go in attempting to increase labor costs and consumer prices above the levels they would reach in free markets? What kinds of coercive conduct practiced by unions against nonunion workers and members of other unions should be allowed? Is there any sound public-policy basis for prohibiting some forms of economically coercive, monopolistic conduct while holding privileged other forms which are indistinguishable from the first in terms of economic purpose and effect?

As we review current legal developments we shall see that clear, consistent, and

\footnotetext{
${ }^{26}$ E.g., United States v. Employing Plasterers Ass'n of Chicago, 347 U.S. I86 (1954); Gilmour v. Wood, Wire \& Metal Lathers Local 74, 223 F. Supp. 236 (N.D. Ill. 1963); United States v. Hamilton Glass Co., 155 F. Supp. 878 (N.D. Ill. I957) (glaziers); United States v. Bay Area Painters \& Decorators Joint Comm., 49 F. Supp. 733 (N.D. Cal. 1943); United States v. Central Supply Ass'n, 40 F. Supp. 964 (N.D. Ohio I94 I), 6 F.R.D. 526 (N.D. Ohio I947) (plumbers); United States v. Carrozzo, 3 CCH Lab. Cas. 160,282 (N.D. Ill. I94I), aff'd per curiam stub nom., United States v. Hod Carriers Dist. Council, 313 U.S. 539 (1941) (hod carriers); Building Contractors Employers Ass'n' v. Gugliemelli, 128 N.Y.L.J. 59, $22 \mathrm{CCH}$ Lab. Cas. I 67,065 (N.Y. Sup. Ct. I952) (masons).
} 
coherent thinking along these lines is sadly lacking in some of the relevant legislation and judicial decisions.

\section{III}

\section{National Labor Policy and Restrictive Union Practices}

\section{A. Regulation of Predatory Practices}

If we turn first to what I have been calling "predatory practices," we find the statutory prescriptions largely consistent but interpretation confused and administration weak. There is no doubt that trade-union violence is as unlawful as any other kind. Besides violating common-law principles and state laws, it also violates section 8(b) (I) (A) of the National Labor Relations Act, ${ }^{27}$ which makes it an unfair practice for a union to restrain or coerce employees in the exercise of their right to refrain from joining unions, from bargaining collectively, and from participating in concerted activities. $^{28}$ On the other hand, the National Labor Relations Board frequently finds it extraordinarily difficult to attribute to unions the responsibility for violence on picket lines which the unions themselves have set up for the purpose of blocking access to the picketed premises. ${ }^{29}$ Moreover, although the Supreme Court has clearly indicated a belief that the Labor Board has power to make unions pay for the harm caused by their violence, ${ }^{30}$ the Board continues to insist that it does not have such power. ${ }^{31}$ The Board has never ordered a union to compensate employees for the wages they have lost when a violent and obstructive picket line has prevented them from reporting for work. A mere cease-and-desist order after violence has occurred and the dispute has ended carries little deterrent effect. Since the Board imposes no effective deterrent, it may fairly be said that, under the Board's administration, the Taft-Hartley policy against trade-union violence has been less effective than it might have been. If this form of monopolistic union conduct is to be checked, therefore, Congress must specifically provide for appropriate sanctions in future legislation. ${ }^{32}$

Stranger-picketing of a construction project by a union seeking to oust a nonunion subcontractor has long been considered an unfair labor practice. Section 8(b)(4)(A) of the Taft-Hartley Act (which became section 8(b) (4)(B) ${ }^{33}$ in 1959, with the passage of the Landrum-Griffin amendments) made it an unfair practice for a union to

\footnotetext{
${ }^{2 \pi} 29$ U.S.C. $\$ 158(b)(I)(A)(1964)$.

${ }^{28}$ The leading NLRB decision is International Longshoremen's Union, 79 N.L.R.B. 1487 (1948). For a recent case involving violence by a construction union, see Gulf Coast Bldg. \& Constr. Trades Council v. F. R. Hoar \& Son, Inc., 370 F.2d 746 (5th Cir. 1967).

sec, e.g., Retail Store Union, I33 N.L.R.B. 1555 (196r).

${ }^{80}$ See UAW v. Russell, 356 U.S. 634 (1958), especially where, speaking for the Court, Justice Burton said of a person who had lost wages as a result of union violence, "We assume, for the purpose of the argument, that the Board would have had authority to award back pay to Russell." Id. at 64I.

${ }^{3 x}$ 'The leading Board decision' is United Furniture Workers, 84 N.L.R.B. 563 (I949).

32 See generally S. Petro, How the NLRB Can Stop Union Violence (Labor Policy Ass'n, 1958), for a 'more extended critique of the Board's policy on violence.

${ }^{38} 29$ U.S.C. $\S I_{5} 8(b)(4)$ (B) $(1964)$.
} 
induce a work stoppage where an object was forcing or requiring one employer to cease doing business with another. Picketing of a construction project on which a nonunion subcontractor is engaged falls comfortably within the prohibition: the immediate object is to induce or encourage workers in the other trades to cease working till the nonunion subcontractor is dismissed, and thus the requisite objective of fracturing a business relationship may also readily be inferred. Over contentions that such picketing is simply "primary"action-not a "secondary boycott"-the Supreme Court of the United States held in the Denver case, as early as I95I, that a plain violation of the statute was involved. ${ }^{34}$

In the years since the Taft-Hartley Act was passed, and since the Denver case was decided, the Labor Board has found numerous loopholes in the proscriptions of section 8(b) (4). These loopholes have acquired such exotic names as "roving situs," "common situs," "allies," "primary action," and so on..$^{35}$ Upon occasion, as we shall see, a construction union manages to slide through one or another of these loopholes by fitting its violation of the Act precisely into the requisite mold. But employers are often astute to checkmate such conduct by appropriate adjustments of the construction project.

Comprehensive treatment of all the moves and countermoves occasioned by the Labor Board's jurisprudence would take much more time and space than are available here. We shall have to content ourselves with one example. The Labor Board's "roving situs" doctrine holds that where the employer with whom a union is disputing has no fixed situs which may be picketed "satisfactorily," the union may follow the "situs" till it comes to rest somewhere, and picket it there. ${ }^{36}$ Translated into realistic language, what this means is that the Board gives unions a privilege to picket the employer at the location where the picketing is likely to do the union the most good and the employer and his nonunion employees the most harm. Thus, if the Teamsters wish to compel unionization of truckdrivers who do not themselves wish to join, it will do the union little good to picket the owner of the trucks at his home terminal; picketing there will impose no coercive pressure upon either the owner or his employees. Accordingly the Board holds, under what are called the "Moore-Drydock Rules,"37 that in a roving situs situation the union may picket the trucks or other such "situs" at the terminal points where they come into contact with someone who, by respecting the picket line, will put pressure on the recalcitrant employer and employees to accept and recognize the union. It is necessary, however, for the union to hold its mouth just right if it wishes the cover of the "MooreDrydock Rules." It must identify the roving situs as the sole object of the picketing

\footnotetext{
${ }^{34}$ NLRB v. Denver Bldg. \& Constr. Trades Council, 34I U.S. 675 (195I).

${ }^{35}$ See generally S. Petro, How the NLRB Repealed TAFT-Hartiey (Labor Policy Ass'n, 1958), for an extended review of the Board's doctrines.

${ }^{30}$ The leading Board decision is Teamsters Local 807, 87 N.L.R.B. 502 (r949).

${ }^{87}$ Sailors' Union of the Pacific, 92 N.L.R.B. 547 (1950).
} 
and disavow any suggestion that the dispute is with the employer located at the picketing site. ${ }^{38}$

Probably because the construction unions rarely are interested in organizing the nonunion employees of offending subcontractors-their interest lying mainly instead in replacing the nonunion subcontractor with a unionized one-the "roving situs" loophole has never been a comfortable fit for them. The United States Court of Appeals for the Sixth Circuit has indeed recently affirmed a Board finding that a construction union had availed itself properly of the "Moore-Drydock Rules."30 But the loophole will not often be useful if employers continue to establish "separate gates" for the employees of nonunion subcontractors on construction projects. When such separate gates are used, the union must picket only there; and of course picketing so confined will not act as a signal to workers in the other trades. ${ }^{40}$

The efficacy of stranger picketing as a means of restricting competition from nonunion workers has been substantially reduced since the enactment of the Landrum-Griffin Law in 1959 , and particularly of section $8(b)(7) .^{41}$ That provision outlaws stranger picketing for recognition or organizational purposes where (a) the employer is lawfully recognizing another union, or (b) an election has been held among the picketed employees within the preceding year, or (c) in any event for more than thirty days without seeking an election. The last subdivision is qualified by a proviso which exculpates picketing designed solely to inform the public of the existence of a labor dispute, providing such picketing does not have the effect of inducing a work stoppage. Only last year, the Ninth Circuit upheld the Board in finding that the Carpenters violated section $8(\mathrm{~b})(4)$, despite the fact that the picketing placards at a construction project were "Directed to Consumers Only." ${ }^{\text {"2 }}$ The picketing having induced a pipefitter to walk off the job, the probability is that it would also have been held a violation of section $8(b)(7)$ had the complaint been framed in terms of that section.

It may be concluded from the foregoing review that the various statutory restrictions upon peaceful but coercive union methods of ousting nonunion labor are being applied with some consistency. A decision handed down on June 30,1967 , suggests that the Labor Board may be inclined to apply the law in the future with even more regard for congressional intent. The case involved picketing of a construction project by the Sheet Metal Workers Union as a means of ousting a nonunion subcontractor. $^{43}$ Cooperating with the Sheet Metal Workers, the Bricklayers' business agent instructed union bricklayers to respect the picket line. When some refused

\footnotetext{
${ }^{38}$ Id. at 549 .

${ }^{30}$ Rommel-McFerran Co. v. Local 369, IBEW, 361 F.2d 658 (6th Cir. 1966).

${ }^{10}$ See Orange Belt Dist. Council of Painters v. NLRB, 361 F.2d 70 (D.C. Cir. 1966); Building $*$ Constr. Trades Council of New Orleans, 155 N.L.R.B. 319 (1965).

${ }^{42} 29$ U.S.C. $\$ 158(\mathrm{~b})(7)(1964)$.

42 NLRB v. Carpenters Local 550, 367 F.2d 953 (9th Cir. 1966).

${ }^{13}$ Bricklayers Local 2, I66 N.L.R.B. No. 26 (I967).
} 
to do so, the Bricklayers Union fined them $\$ 25$ each. In a 2-I decision, with Member Brown dissenting, the Labor Board ruled the act of fining disobedient members amounted in itself to the inducement or encouragement of a work stoppage prohibited by section 8(b) (4)-and ordered the Bricklayers to make restitution of the amounts of the fines. Member Brown's dissent was only to the restitution order, which he thought exceeded the Board's powers. But since the Act empowers the Board to issue any affirmative order reasonably calculated to remedy unfair practices and to effectuate the policies of the Act, ${ }^{44}$ it would seem that the restitution order lay well within the Board's powers. Perhaps, now that the Board has issued a money order in a section $8(\mathrm{~b})(4)$ case it will reconsider its anomalous opinion that it without power to make compensatory money awards in cases in which unions have caused wage losses by violent conduct.

So fat as peaceful economic coercion by construction unions is concerned, the pressing need now is for speedy, consistent, and vigorous enforcement of the substantive law. On the assumption that peaceful anticompetitive conduct is a fit subject for government regulation, the statute and to a lesser degree the substantive interpretations are comprehensive and coherent. If enforcement were improved, the prospects of keeping the monopolistic tendencies of the construction industries under control would be much brighter than they are. Quite possibly, completely effective enforcement of the competitive policies of the Labor Relations Act will never come so long as the Labor Board has a virtual monopoly of enforcement, for many builders and contractors will yield to unlawful union demands merely because it is so complicated and takes so long to get relief via the Labor Board's processes. ${ }^{45}$ If the Norris-LaGuardia $\mathrm{Act}^{46}$ were repealed, or even if it were only amended to permit direct suits for injunctive relief against union unfair practices, it seems fairly predictable that the resistance of builders and contractors would grow-and that the present highly monopolistic control over the labor market exerted by the construction unions would be brought down to tolerable proportions.

\section{B. Regulation of Contractual Restrictions}

\section{r. The Closed Shop}

It is a matter of common gossip in the trade that, the Taft-Hartley Act to the contrary notwithstanding, closed shop conditions largely prevail in the construction industry. The act itself prohibits the closed shop and all other contractual arrange-

\footnotetext{
4\$ $\$ 10(c), 29$ U.S.C. $\S 160(c)$ (1964). See generally S. Petro, supra note 32; Note, Back Pay Awards Against Unions Under the LMRA, 51 CoLUM. L. REv. 508 (195I).

${ }^{45}$ See NLRB v. Lexington Elec. Prods. Co., 283 F.2d 54 (3d Cir. 1960), where the Board imposed a heavy penalty on an employer for participating in an unlawful compulsory-unionism agreement, despite the fact that the employer resisted till he learned that the Board would not take action against the union's unlawful pressures.

${ }^{10} 29$ U.S.C. $\$$ roI-I $5(1964)$. This Act, generally speaking, virtually erases the power of the federal courts to grant injunctive relief in labor disputes where the petitioner is a private party.
} 
ments which require union membership as a hiring condition. ${ }^{47}$ Generally speaking, majority unions may negotiate for only such compulsory-unionism agreements as require union membership after employment has begun, although in section 8(f) the act permits construction unions to negotiate such contracts even before they have established majority status.

For a certain period beginning during the Eisenhower administration, the Labor Board had been holding that hiring through unions violated the act even though the unions undertook contractually to refer union and nonunion men indiscriminately for employment. ${ }^{48}$ However, the rule is now different. Unions may now bargain and even strike to gain administrative control of the hiring process unless the contractual proposal on its face provides for discrimination in favor of union members. ${ }^{49}$ As Judge Bell put it in a recent decision, "No doubt union membership will be encouraged under the arrangement, indeed it may be a boon to the union; nevertheless such an arrangement does not constitute compulsory unionism so long as the arrangement is not employed in a discriminatory manner."

The prevalence of closed shop conditions in the construction industry undoubtedly traces in part to such restrictive interpretation of the national policy against compulsory unionism. Beyond much question, moreover, hiring through unions in the construction trades rests to some extent on valid economic grounds: it is simply most convenient and even most economic in some cases to rely upon unions and their hiring halls for competent journeymen. But to a substantial extent, probably, contractors yield to effective closed shop conditions because the construction unions are in a position to hurt them badly if they resist, and because the law affords no speedy and effective protection to a resisting employer. ${ }^{51}$ Injunctive relief in state courtseven in states which have right-to-work-laws-is barred by the pre-emption doctrine; ${ }^{62}$ and it is barred in the federal courts by the Norris-LaGuardia Act. ${ }^{53}$ The employer confronted by a union demand for effective closed shop conditions must either yield or rely upon the long, drawn-out processes of the Labor Board. When it finally comes, the relief afforded by the Board is too little, and much too late. ${ }^{54}$

Considerable publicity has been directed in recent years to the tendency among construction unions to deny admission to members of minority groups, and it is widely

\footnotetext{
${ }^{17} \S \S 8(a)(3),(b)(2), 29$ U.S.C. $\$ \S 5_{5} 8(a)(3)$, (b)(2) ( 1964$)$, permit a modified type of "unionshop" agreement under which union membership of a highly limited type may be required after a person has been hired.

${ }^{48}$ See NLRB v. H. K. Ferguson Co., 337 F.2d 205 (5th Cir, 1964).

${ }^{60}$ The basic Supreme Court decisions were: Local 60, Carpenters v. NLRB, 365 U.S. 651 (1961); Local 357 , Teamsters v. NLRB, 365 U.S. 667 (Ig6r); NLRB v. News Syndicate Co., 365 U.S. 695 (I96r).

${ }^{80}$ NLRB v. Houston Chapter, Associated Gen. Contractors, 349 F.2d 449, 453 (5th Cir. 1965).

${ }^{61}$ See, e.g., NLRB v. Lexington Elec. Prods. Co., 283 F.2d 54 (3d Cir. I960).

${ }^{62}$ Local 438 , Construction \& Gen. Laborers' Union v. Curry, 37 I U.S. 542 (1963); Local 429, IBEW v. Farnsworth \& Chambers Co., 353 U.S. 969 (1957). Compare Retail Clerks, Local 1625 v. Schermerhorn, 373 U.S. 746 (1963).

${ }^{53} 29$ U.S.C. \$\$ ror-15 (1964).

54 See NLRB v. Lexington Elec. Prods. Co., 283 F.2d 54 (3d Cir. 1960); Note, supra note 14.
} 
recognized that this denial of membership amounts to a denial of employment. Certainly the ambitions of Negroes for social and economic advancement would be helped along if they had easier access to the skilled trades, for such has been the path of progress in the case of members of many other minority groups. Moreover, general consumer interests would be well served if the severe shortages which have prevailed in the skilled trades for many years could be eased.

The case for breaking down the closed shop conditions of the building industry is thus a particularly strong one. Whether or not such conditions can ever be removed completely, one may doubt-especially since, as has been noted, they rest to some extent on valid economic grounds. But if all forms of compulsory unionism were unequivocally outlawed, and if employers were granted direct access to the courts for relief from union pressures, the chances are good that entry into the skilled trades would be facilitated for members of minority groups, and that labor market conditions in the construction industry would thus be eased. Undoubtedly wage rates would remain high; they are bound to be so as long as our government continues its inflationary course. But the upward pressures would be bound to diminish; construction costs, it may be hoped, would quit climbing so steeply; the industry might enjoy a steadier future than its boom-and-bust past; and the consumer would certainly be better off.

\section{2. "Hot Cargo" Contracts}

Congress has long been preoccupied with union conduct aimed at restricting employer access to competitive labor and product markets and has prohibited it in the strongest and plainest terms. Yet the Labor Board and the Supreme Court of the United States have established monopolistic privileges for trade unions of the precise kind which Congress has condemned. Despite the most unequivocal congressional expression of intent to outlaw "hot cargo" contracts, the Labor Board and the Court have held that they are lawful where designed to preserve for the participating union's members the kinds of work that they have traditionally performed. These decisions are likely to have antisocial consequences throughout the economy. But their impact will be especially costly in the construction industry, where technological progress has been delayed so long and is so pressingly needed.

Before reviewing the authorities, let us briefly inspect the statutory scheme. Twenty years ago, in enacting the Taft-Hartley Act by overwhelming majorities in both the House and the Senate, Congress demonstrated a clear intent to prohibit unions from dictating or even attempting to dictate the relations which employers might form with other persons, whether workers or other businessmen. The principal measure was section $8(\mathrm{~b})(4) .55$ That section made it an unfair practice for a union to induce or encourage a work stoppage where "an object" was forcing or requiring any person to "cease using, selling, handling, transporting, or otherwise

\footnotetext{
"Ch. I20, $\$$ I0r, 6r Stat. I4I (1947), as amended, 29 U.S.C. $\$$ 158(b)(4)(A), (B) (1964).
} 
dealing in the products of any other producer, processor, or manufacturer, or to cease doing business with any other person."

There would seem to be little question that a faithful application of the literal meaning and the spirit of the foregoing language should have led to the effective prohibition of any attempt to negotiate for, to enter into, or to enforce a "hot cargo" contract. For the essence of such contracts is that they require employers to cease dealing with other employers or in their products. Moreover, a "hot cargo" clause, like every other bargaining objective of a union, is secured by either a strike or a threatened strike. Employers have a common law right to deal or not to deal with other employers as they wish. They do not need a collective agreement in order either to establish or to exercise that right. The collective agreement can only take it away; can only involve a concession by the employer to the union. Like every other concession, it is yielded because the employer would rather yield than take a strike. Thus, negotiating for a "hot cargo" contract would seem clearly to involve a violation of section $8(b)$ (4).

Moreover, the contract itself, once entered, would seem equally to violate the section. This conclusion follows because, once negotiated, the contract is itself a continuous inducement to a work stoppage whenever the employer deals with, or in the products of, the employer proscribed by the contract. The statute does not exclude contracts from the category of prohibited inducements. It outlaws inducements without qualification. To hold that the contract does not amount to the kind of inducement prohibited by the statute would be to hold that a private contract supersedes a congressionally declared policy-something which the Labor Board has consistently denied in all cases except those involving "hot cargo" agreements.

Finally, if due respect is to be accorded to statutory language, it would seem that an actual work stoppage occasioned by the employer's flouting the "hot cargo" clause should be held a violation of section $8(\mathrm{~b})(4)$. For a work stoppage induced by the employer's doing business with some other person falls squarely within the language of section $8(\mathrm{~b})(4)$; hence it could be exonerated only on the theory that the contract negated the statute. But that theory must be rejected on the ground stated above.

Notwithstanding the strength and the clarity of the foregoing analysis, the Labor Board held for some time that a union did not violate section 8(b) (4) either in negotiating for, or entering, or even in striking to enforce a "hot cargo" contract..$^{\text {bT }}$ Later the Board held that while the contract was in itself unobjectionable, a strike to

\footnotetext{
${ }^{6 B}$ National Licorice Co. v. NLRB, 309 U.S. 350 (1940); Utility Workers v. Consolidated Edison Co., 309 U.S. 26I (I940); $c f$. Garner v. Teamsters Local 776, 346 U.S. 485 (1953); Wallace Corp. v. NLRB, 323 U.S. 248 (1944); Sun Ship Employees Ass'n v. NLRB, 139 F.2d 744 (3d Cir. 1943); NLRB v. General Motors Corp., II6 F.2d 306 ( 7 th Cir. 1940).

${ }^{57}$ Local I35, Teamsters, 105 N.L.R.B. 740 (1953); Teamsters, Local 294, 87 N.L.R.B. 972 (1949), enforced, Rabouin v. NLRB, r95 F.2d 906 (2d Cir. 1952) (L. Hand, J., dissenting). See generally S. Petro, supra note 35, at 103-07, for a detailed review of the NLRB's views of the legality of "hot cargo" action.
} 
enforce it constituted a violation of section $8(\mathrm{~b})(4) .{ }^{58}$ Still later, the Board came to the conclusion that a "hot cargo" clause was itself unlawful in the trucking industry, on the theory that common carriers have a duty to serve all without discrimination. ${ }^{59}$

The Board's middle position received the approval of the Supreme Court in 1958, in the Sand Door case. ${ }^{60}$ There the Court held that while the contract itself was lawful, the union could not enforce it by calling a work stoppage when the employer departed from the agreement. Incidentally, the contract in Sand Door provided that "workmen shall not be required to handle nonunion material." Nevertheless the general contractors involved in the case ordered doors from the Sand Door \& Plywood Company, a nonunion firm. On orders from the business agent of the Brotherhood of Carpenters, the carpenters refused to install the doors.

Sand Door was much in the minds of Congressmen in 1959, when they were considering the proposals which were to become the Landrum-Griffin Law. ${ }^{61}$ They were concerned especially with the Court's holding that the contract was in itself lawful. This holding, they felt, exposed employers to legal actions for breach of contract. Obviously wishing to make completely effective the Taft-Hartley policy which the Board and the Supreme Court had in part frustrated, they enacted measures which explicitly outlawed union pressures designed to impose "hot-cargo" agreements, as well as the agreements themselves. Landrum-Griffin also continued in section 8(b) (4) (B) the stautory language which the Supreme Court had applied in Sand Door to outlaw work stoppages enforcing "hot cargo" clauses. The new provisions are found in sections $8(\mathrm{~b})(4)(\mathrm{i})$ and (ii) (A) and $8(\mathrm{e}) .^{62}$

The former makes it an unfair practice for a union to induce or encourage any kind of a work stoppage or to "threaten, coerce, or restrain" any person where an object is to force or require him to enter into any agreement prohibited by section 8(e). Section $8(\mathrm{e})$ in turn provides as follows:

It shall be an unfair labor practice for any labor organization and any employer to enter into any contract or agreement, express or implied, whereby such employer ceases or refrains or agrees to cease or refrain from handling, using, selling, transporting or otherwise dealing in any of the products of any other employer, or to cease doing business with any other person, and any contract or agreement entered into heretofore or hereafter containing such an agreement shall be to such extent unenforcible and void ....

The section contains three provisos, two entirely negating the Act's boycott proscriptions in the garment industry, and one fragmentarily modifying the section 8 (e) boycott proscriptions in the construction industry. The latter provides that

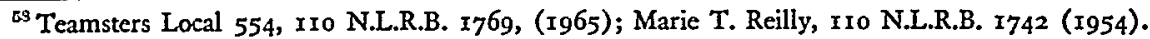

${ }^{60}$ Local 728, Teamsters, II9 N.L.R.B. 339 (1957).

${ }^{\circ 0}$ Local 1976 , Carpenters v. NLRB, 357 U.S. 93 (1958).

oI See National Woodwork Mfrs. Ass'n v. NLRB, 386 U.S. 6r2, 634-44 (1967).

${ }^{02} 29$ U.S.C. $\$ \$ 158(\mathrm{~b})(4)$ (i), (ii)(A), 158 (e) (1964).
} 
nothing in this subsection (e) shall apply to an agreement between a labor organization and an employer in the construction industry relating to the contracting or subcontracting of work to be done at the site of the construction, alteration, painting, or repair of a building, structure, or other work.

Read sensibly in connection with the enacting clause, this proviso would privilege, say, the Carpenters Brotherhood in negotiating an agreement establishing its jurisdiction over given work at the construction site. For example, the Carpenters might insist that installing wallboard should be a function for carpenters rather than lathers. The emphasis in the proviso on construction-site work and its silence with respect to the product boycotts prohibited by both section $8(\mathrm{~b})(4)$ and the enacting clause of section 8(e) have clear import. They necessarily imply that Congress apparently intended by the enacting clause of section $8(\mathrm{e})$ to keep construction unions from interfering with the employer's choice of product, while permitting them to attempt to induce construction contractors to allocate work at the building site in certain ways. Thus, in our example, the carpenter would not be permitted to exclude the wallboard itself, although they could lawfully bargain for the job of installing it. This interpretation fits smoothly and well with other congressional policies applicable in the construction industry. For example, in section ro(k) of the Act, Congress has encouraged the development of private arbitration techniques for the settlement of jurisdictional disputes. ${ }^{63}$ The construction-site work proviso reflects the same desire to promote consensual work-allocations in the building industry.

Notwithstanding the tolerably simple and clear intent of section $8(\mathrm{~b})(4)(\mathrm{A})$ and section 8(e) thus revealed, the Labor Board-and more recently the Supreme Court, too-have already managed to confuse its meaning and sharply to reduce its effectiveness. The Board has been holding that construction unions may strike in order to secure "hot cargo" clauses, if the clauses bear any relationship to work which has ever been done at the construction site. ${ }^{64}$ The theory is that if certain work has been done at the site in the past, an agreement forestalling the use of products incorporating that work comes within the privilege established by the construction-site provision. ${ }^{65}$

The Board's theory is carried through with some coherence. For example, it holds that if a contractor is bound by specifications calling for the use of certain products, a union may not lawfully refuse to install those products even though they incorporate work historically done at construction sites. ${ }^{66}$ Again, the Board withholds

\footnotetext{
${ }^{63}$ Cf. Carey v. Westinghouse Elec. Corp., 375 U.S. 261 (1964); NLRB v. Radio Engincers, Local 1212,364 U.S. 573 (r96I); Local 68, Wood, Wire \& Metal Lathers, 142 N.L.R.B. 1073 (1963).

of For a clear account of the Board's position, see NLRB v. Muskegon Bricklayers Local 5, 55 CCHI Lab. Cas. If I 1996 (6th Cir. 1967 ). See also NLRB v. IBEW, Local 683, 359 F.2d 385 (6th Cir. 1966); NLRB v. Local 217 , Plumbers, 36r F.2d r60 (xst Cir. 1966).

os But not if the agtcement reserves the right to cease work if any nonunion workers, regardless of craft, are employed. Cf. NLRB v. Muskegon Bricklayers Local 5, $55 \mathrm{CCH}$ Lab. Cas. \11,996 (6th Cir. rg67).

${ }^{\circ 6}$ See National Woodwork Mfrs. Ass'n v. NLRB, 386 U.S. 612, 615-16 nn.2 \& 3 (1967).
} 
approval from "hot cargo" clauses addressed expressly to nonunion-made products as such. In short, the Board holds consistently that "hot cargo" clauses are valid only when they are narrowly and essentially confined to preserving work under the contractor's control that has traditionally been done at the job-site.

In his opinion for the bare majority which upheld the Board's decision in the National Woodwork case, Mr. Justice Brennan adopted a far more complex and far less acceptable mode of analysis. While bowing frequently to the primacy of congressional intent and to the necessity of applying the "spirit" of statutes, ${ }^{87}$ what he actually did amounted to a thorough flouting of both.

National Woodwork is the case involving a refusal by union carpenters to install pre-assembled doors. The Carpenters Brotherhood had negotiated a collective agreement with a contractor's association. Rule seventeen of the agreement provided that no member of the Brotherhood would "handle ... any doors . . . which have been fitted prior to being furnished on the job." ${ }^{\text {"68 }}$ Rule seventeen also prohibited nonunionmade materials, but the Labor Board held that the bocyott of nonunion materials was an unfair practice, and the union did not appeal that holding, so it did not figure in the Supreme Court's opinion. ${ }^{69}$

Although Mr. Justice Brennan did not concede that section 8 (e) was unambiguous, he said that even if it were clear on its face the Court would still be obliged to apply it consistently with the "spirit" of the legislation. ${ }^{\mathbf{7 0}} \mathrm{He}$ then proceeded to develop what Mr. Justice Stewart, dissenting, called a "protracted review of legislative and decisional history in an effort to show that the clear words of the statute should be disregarded in these cases."71

In support of his conclusion that sections $8(\mathrm{~b})(4)(B)$ and $8(e)$ were not intended to outlaw "work-preservation" product boycotts, Mr. Justice Brennan did cover considerable ground. The basic framework of his analysis, however, is astonishingly simple, once uncovered. His syllogism runs as follows: Congress intended to forbid secondary boycotts; work-preservation product boycotts are primary in character; hence they are not prohibited.

Some ten years ago I wrote a long, exhaustively-documented technical monograph demonstrating that the "primary-secondary" dichotomy was a pure figment of the Labor Board's imagination, bearing no relationship to the objectives of Congress as set out in either the Taft-Hartley Act or its legislative history. ${ }^{\mathbf{7 2}}$ Moreover, the weight of authority in the federal courts, till the Supreme Court imposed the Board's dichotomy

\footnotetext{
${ }^{67}$ E.g., id. at 6rg, 644 .

${ }^{08} \mathrm{Id}$. at $6 \mathrm{r}_{5} \mathrm{n} .2$.

${ }^{\circ}$ Id. at $6 \mathrm{r} 6 \mathrm{n} .3$.

${ }^{70} \mathrm{Id}$. at $6 \mathrm{rg}$.

${ }^{71} I d$. at 650 .

${ }^{72} \mathrm{~S}$. PETro, supra note 35 , especially at $35-49,7 \mathrm{I}-\mathrm{IrO}$, where the legislative history of the TaftHartley Act is comprehensively reviewed in order to demonstrate that neither it nor the statutory language supported the "primary-secondary" dichotomy.
} 
on them, ${ }^{73}$ was of the same opinion. For example, the Ninth Circuit said that "the statute . . . does not use the terms 'hot cargo,' 'picketing the product,' or 'secondary boycott.' It broadly sweeps within its prohibition an entire pattern of industrial warfare deemed by Congress to be harmful to the public interest."74 Writing for the Second Circuit, Judge Augustus Hand said that "it seems idle . . . to argue that only such 'secondary boycotts' as were unlawful at common law, or under the law of some particular state fall within the prohibitions of [section $8($ b) (4)]."75 The Fifth Circuit perhaps put the weakness of the "primary-secondary" dichotomy in the clearest form when it said: ${ }^{66}$

The statute clearly provides a remedy for the type of conduct engaged in by the union, without resort to any distinction between primary and secondary activities. If the union's activities come within the language of the statute, they constitute an unfair labor practice, regardless of whether they might have been considered a true "secondary boycott" under the old common law or any of the modern and popular theories.

In the face of the foregoing it is extremely difficult to accept Justice Brennan's assertion that "judicial decisions interpreting the broad language of $\S 8(\mathrm{~b})(4)(\mathrm{A})$ of the Taft-Hartley Act uniformly [sic] limited its application to such 'secondary' situations"; 77 or to accept his reference to "the scholarly acceptance of this primarysecondary dichotomy."78

In an attempt to demonstrate that section 8(b) (4) of the Taft-Hartley Act was totally preoccupied with "secondary" conduct, Justice Brennan argued that subdivision (B) thereof dealt with a situation where pressure was brought upon one employer to force another to recognize an uncertified union; that subdivision $(C)$ forbade one union to induce a work stoppage in order to compel recognition by an employer who was dealing with another, certified, union; and that subdivision (D) prohibited work stoppages designed to compel an employer to assign to the strikers work which he had already assigned to members of another union. ${ }^{70}$

All these subdivisions, said Brennan, were "limited to protecting employers in the position of neutrals between contending parties."80 Or again: "The central theme pervading these provisions of protection for the neutral employer confirms the assurance of those sponsoring the section that in subsection (A) Congress likewise

\footnotetext{
${ }^{73}$ Principally in NLRB v. International Rice Milling Co., $34 \mathrm{I}$ U.S. 665 (I95I).

${ }^{7 *}$ Printing Union, Local 388 v. LeBaron, $x 71$ F.2d 331, 334 (9th Cir. I948).

${ }_{76}$ NLRB v. Wine Workers Union, Local I, I 78 F.2d 584, 587 (2d Cir. I949).

${ }^{76}$ International Rice Milling Co. v. NLRB, 183 F.2d 21, 26 (5th Cir. 1950), rev'd, 341 U.S. 665 (195I).

${ }^{77} 386$ U.S. at 626 . Justice Stewart's dissenting opinion accepts Justice Brennan's version of the "primary-secondary" dichotomy but feels that the Carpenters' boycott of pre-assembled doors is a violation of $\$ 8(\mathrm{e})$, anyway. Id. at 651-52.

${ }^{78}$ Id. at 626 n.r 6 .

${ }^{70} I d$. at $625-26$.

${ }^{80} \mathrm{Id}$. at 625 .
} 
meant to protect the employer only from union pressures designed to involve him in disputes not his own."81

The subdivisions cited by Justice Brennan are far from establishing his conclusion. It must be noted in the first place that Justice Brennan left out a significant feature of section 8(b)(4)(A). That section includes a clause which makes it an unfair practice for a union to strike where an object is forcing or requiring "any employer or self-employed person to join any labor or employer organization." Quite obviously, under any presently prevailing concept of the "secondary boycott," such a strike would not be considered "secondary." This clause of section $8(\mathrm{~b})(4)(\mathrm{A})$ discloses the basic weakness of Justice Brennan's analysis. It is too bad he did not notice its existence.

However, the analysis is insupportable anyway, and section $8(\mathrm{~b})(4)(\mathrm{D})$-when presented fully-quite adequately reveals the shortcomings of his analysis. Subdivision (D) does not limit itself to work assignment disputes between contending unions, as Justice Brennan apparently believed. On the contrary, it forbids a union to strike for jobs, not only when those jobs are being filled by members of another union - but also when the jobs have been assigned unilaterally by the employer to nonunion men. The full relevant text makes it unlawful for a union to force or require "any employer to assign particular work to employees in a particular labor organization or in a particular trade, craft, or class rather than to employees in another labor organization or in another trade, craft, or class." 82

When the full text of subdivision (D) is considered, it becomes apparent that the provision does not bespeak, as Justice Brennan believes, a congressional concern confined to "neutral" employers. ${ }^{83}$ The employer who assigns to nonunion men jobs which unions wish to take for their own members is not a "neutral" in any intelligible sense of that term. He is as direct a participant in the dispute as anyone else. His decision, his work assignment, is what the union objects to.

The employer who assigns union-claimed work to nonunion men stands with

\footnotetext{
${ }^{81}$ Id. at $625-26$.

${ }^{82} 29$ U.S.C. $\S 158($ b) (4)(D) (I964). (Emphasis added.) The description of $\S 8(\mathrm{~b})(4)$ (D) carried
} in $3 \mathrm{CCH}$ LAB. L. REP. If 5230 is revealing. It says:

"The term 'jurisdictional strike' is commonly applied to work-assignment disputes of the

kind covered by Section $8(\mathrm{~b})(4)(D)$, since they often arise as a result of rival unions' conflicting claims to particular work, and since only strikes or inducement of work stoppages were forbidden methods of coercing work assignments before the 1959 amendments. However, the coverage of Section $8(b)(4)(D)$ is much broader than the conduct involved in a traditional jurisdictional strike. It also covers situations involving only a single union, when that union secks to compel assignment to its members of work being performed by an employer's unorganized employees. . . . Both primary and secondary activities are included in Section 8(b)(4)(D)'s ban . ..." Cases agreeing with this comment and holding that the section applies to both "primary" and "secondary" action are: Dooley v. Local 107, Teamsters, $39 \mathrm{CCH}$ Lab. Cas. 166,288 (D. Del. I960); Local 450, Operating Engineers v. Elliott, 256 F.2d 630 (5th Cir. I958); ILA Local 1351, ro8 N.L.R.B. 7 I2 (1954). For decisions holding that $\$ 8(\mathrm{~b})(4)(D)$ is not violated where the dispute is between a union and nonunion employees despite the plain language of the section-see Schauffer v. Local 129r, Longshoremen, 292 F.2d I 82 (3d Cir. I96r); Cuneo v. Local 472, Hod Carriers, I75 F. Supp. r3r (D.N.J. I959).

${ }^{83} 386$ U S. at 622 . 
respect to the union in precisely the same relationship as the contractor who orders products to which a construction union is opposed. He has chosen to contract with someone else in a way which reduces the amount of work controlled by the union. The fact that subdivision (D) forbids unions to interfere in the work assignments made by employers refutes Justice Brennan's theory that section $8(\mathrm{~b})(4)$ is concerned only to protect "neutrals," as well as his theory that in section 8(b) (4) Congress was interested in limiting only "secondary boycotts." It would seem to establish a fatal defect in his conclusion that a work-preservation boycott should not be held unlawful despite the plain prohibition of the statute, because it is "primary" action.

In reaching his conclusion, Justice Brennan was compelled to grapple with the fact that Congress had been dramatically intent upon outlawing the kind of union conduct revealed in the Allen Bradley case. ${ }^{84}$ There, it will be remembered, Local 3 of the International Brotherhood of Electrical Workers had joined with New York City manufacturers and contractors to bar electrical products manufactured outside the City. The Supreme Court had held that it would have exonerated the boycott but for the fact that the union had combined with employer groups to effectuate it. This qualification disturbed Congress. In passing the Taft-Hartley Act, therefore, Congress made explicit its intention to outlaw such boycotts even where they were conceived and effectuated by unions acting alone. ${ }^{85}$ Since the boycott in National Woodwork strongly resembled the Allen Bradley boycott, and since the Allen Bradley boycott admittedly fell within the words and the "spirit" of the statute, it was incumbent upon Justice Brennan to distinguish the cases. This he did by asserting that the Allen Bradley boycott was designed to increase the work governed by Local 3, while the Carpenters in National Woodwork were intent upon preserving work that they had done in the past: "[T] $]$ he boycott in Allen Bradley was carried on not as a shield to preserve the jobs of Local 3 members, traditionally a primary labor activity, but as a sword, to reach out and monopolize all the manufacturing tasks for Local 3 members."

Here too it is possible that Justice Brennan had not got the facts quite straight. In his dissenting opinion, Justice Stewart pointed out that:

Just as in the case before us, the union [in Allen Bradley] enforced the product boycott to protect the work opportunities of its members. ...87

$\ldots[\mathrm{I}] \mathrm{t}$ is misleading to state that the union in Allen Bradley used the product boycott as a "sword." The record in that case establishes that the boycott was undertaken for the defensive purpose of restoring job opportunities lost in the depression. Moreover, the Court is unable to cite anything in Allen Bradley, or in the Taft-Hartley Act and its legislative history, to support a distinction in

\footnotetext{
${ }^{84}$ Allen Bradley Co. v. Local 3, IBEW, 325 U.S. 797 (1945).

${ }^{85}$ See, e.g., the comments of Senators Ball, Taft, and Ellender, quoted in 386 U.S. at 629-39, 630 n.18,

${ }^{80} I d$. at 630 .

${ }^{87}$ Id. at 653 .
} 655. 
the applicability of $\S 8(\mathrm{~b})(4)$ based on the origin of the job opportunities sought to be preserved by a product boycott. The Court creates its sword and shield distinction out of thin air; nothing could more clearly indicate that the Court is simply substituting its own concepts of desirable labor policy for the scheme enacted by Congress. ${ }^{88}$

After distinguishing Allen Bradley on the basis of the "sword-shield" metaphor, Justice Brennan reverted briefly to textual analysis of section 8(e). Although unable to demonstrate that the enacting language of the section fails to proscribe "workpreservation" product boycotts, he nevertheless insisted that such boycotts are excluded because they are "primary" and because Congress "meant that both $\$ \$ 8(\mathrm{e})$ and 8 (b) (4) (B) reach only secondary pressures." ${ }^{\prime 2}$ According to Justice Brennan, this assertion followed from the necessary implications of the construction-site proviso. That proviso makes sense, he said, only if section 8(e) is preoccupied with "secondary" conduct. Otherwise,

the construction industry proviso, which permits "hot cargo" agreements only for jobsite work, would have the curious and unsupported result of allowing the construction worker to make agreements preserving his traditional tasks against jobsite prefabrication and subcontracting but not against nonjobsite prefabrication and subcontracting. ${ }^{90}$

This language seems unnecessarily difficult and opaque. It is anomalous to speak, in the context of the language of section 8(e), of "jobsite prefabrication." The term "prefabrication" is normally and naturally used in connection with articles or products which come to the jobsite in "prefabricated" or "pre-assembled" form. If Justice Brennan had used language in the normal way, the difficulty he posed would have disappeared. As shown above, there is nothing at all anomalous, perplexing, or contradictory in the relationship of the enacting language of section 8(e) and the jobsite proviso, when the words used are given their normal meaning. Summed up, the enacting language says: no product boycotts; and the proviso says: the work of installing products at the construction site is subject to agreement between union and contractor. Once this clear and simple relationship between the enacting language and the proviso is seen, the difficulty disappears; the "primary-secondary dichotomy" so heavily emphasized by Justice Brennan is seen as a gratuitous irrelevancy; and any doubts concerning the illegality of the Carpenters' boycott of the nonjobsite prehung doors are easily resolved. ${ }^{91}$

It is possible that Justice Brennan's difficulty traced, fundamentally, to his having moved in a circle. Perhaps he began his analysis with the assumption that the jobsite proviso was designed to permit construction unions to negotiate with respect

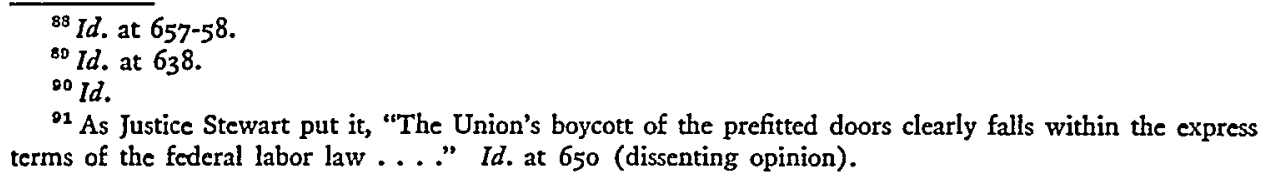


to any kind of work which might conceivably be done at the construction site. But such an assumption is impermissible; for the language of section $8(\mathrm{e})$ and the relationship between that language and the construction-site proviso preclude it. The basic language prohibits without exception all product boycotts. It is possible for a proviso to negate an enacting section. But in order to do so, the language adopted must fit the purpose. For example, had the proviso repeated the language of the enacting section either in terms or in substance, and then said that it was inapplicable in the construction industry, one might rationally conclude that the intent of Congress was to permit the construction unions to negotiate with respect to any kind of work which might conceivably be done at the construction site. But the jobsitework proviso does not purport to negate the whole of section $8(\mathrm{e})$; it carves out a portion of the prohibition.

The point is best made, perhaps, by observing the difference between the construction-site proviso and the adjacent proviso, which does in fact and obvious language entirely negate the applicability of section 8(e) -and of section 8(b) (4)(B)to the garment industry. While the construction-site proviso confines itself to "work to be done at the site of the construction," the garment-industry proviso goes the whole way. It states that

for the purposes of this subsection (e) and section $8(b)(4)(B)$ the terms "any employer", "any person engaged in commerce or an industry affecting commerce", and "any person" when used in relation to the terms "any other producer, processor, or manufacturer", "any other employer", or "any other person" shall not include persons in the relation of a jobber, manufacturer, contractor, or subcontractor working on the goods or premises of the jobber or manufacturer or performing parts of an integrated process of production in the apparel and clothing industry.

Justice Brennan indicated a belief that the garment-industry proviso sustained his conclusion. ${ }^{92}$ But its effect, quite clearly, is the precise contrary. In drafting that proviso, Congress demonstrated its capacity to negate section $8(\mathrm{e})$ in an industry in which it wished to do so. The sharp distinction in its approach to the construction industry establishes an intention to provide there only a fragmentary exclusion from the reach of section $8(\mathrm{e})$. The only fragmentary exclusion which carries an intelligible content is the one which distinguishes between products and work done at the construction site. The House Conference Report demonstrates that Congress had no doubts about that: $:^{93}$

It should be particularly noted that the proviso relates only and exclusively to the contracting or subcontracting of work to be done at the site of the construction. The proviso does not exempt from section 8(e) agreements relating to supplies or

${ }^{92}$ Id. at $637-38$.

${ }^{88}$ H.R. ReP. No. 1 147, 86th Cong., Ist Sess. 39 (1959), quoted by Mr. Justice Stewart, 386 U.S. at 66I-62. 
other products or materials shipped or otherwise transported to and delivered on the site of the construction.

Grappling with Justice Brennan's rationale, dissenting Justice Stewart (and with him Justices Black, Clark, and Douglas) recognized that the majority opinion had been guilty of assuming the answer to the question posed by the case. Justice Stewart said $:^{84}$

The Court indeed recognizes that the . . proviso does not immunize product boycotts .... By a curious inversion of logic, the Court purports to deduce from this fact the proposition that product boycotts are not covered by $\S 8(\mathrm{e})$. But if $\S 8(\mathrm{e})$ and its legislative history are approached without preconceptions, it is evident that Congress intended to bar the use of any provisions in a collective agreement to authorize the product boycott involved in the case before us.

After covering the statute and its legislative history, Justice Brennan sought support for his conclusion in the Fibreboard case, ${ }^{95}$ an earlier ruling to the effect that an employer must in certain circumstances bargain over subcontracting. "It would ... be incongruous," he said, "to interpret $\$ 8(\mathrm{e})$ to invalidate clauses over which the parties may be mandated to bargain and which have been successfully incorporated through collective bargaining in many of this Nation's major labor agreements." "so

Justice Brennan was correct in detecting the existence of an incongruity, but not in identifying it. The Fibreboard decision is itself an anomaly which cannot be squared with either the collective-bargaining policies of the National Labor Relations Act or its policies against union control of jobs. The Act requires collective bargaining over "wages, hours, and other terms and conditions of employment."97 Subcontracting does not fit comfortably into any of these categories. An employer's decision to subcontract an operation, like a decision to substitute machinery for men-indeed, like every decision to buy rather than make-is likely to affect the availability of work in his own operation; but so too, for that matter, is a decision on plant location, choice of product, or even price of product. The point is that affecting the availability of work is by no means the same thing as establishing wages, hours, or other terms of employment-the subject-matter of compulsory collective bargaining. To observe that much collective bargaining concerns itself with subcontracting is not to establish that activity as a compulsory bargaining subject.

Again, compelling employers to bargain over subcontracting clearly flouted the mandate of section 8(e) as well as other congressional proscriptions of job-controlling activities by unions. As we have seen, congressional measures against such job-control are scattered throughout the statute. For example, section 8(b) (2) makes it an unfair practice for a union to acquire closed-shop control or even merely to attempt to

\footnotetext{
ot 386 U.S. at 662 .

05 Fibreboard Paper Prods. Corp. v. NLRB, 379 U.S. 203 (1964).

${ }^{\circ 0} 386$ U.S. at 643 .

${ }^{07} \$ 8(d), 29$ U.S.C. $\$ 158(d)(1964)$.
} 
achieve it. ${ }^{98}$ Section $8(b)$ (4) proscribes union efforts to dictate the parties with whom an employer may deal. And section 8(b) (4)(D) makes it an unfair practice for a union to use pressure as a means of securing for its members work which an employer is assigning to others.

Properly understood, the Fibreboard principle undercuts these statutory policies by encouraging unions to exercise the kind of job-control that so many statutory measures were intended to discourage. Since the principle is not itself based on any necessary implication of the statutory language, the Fibreboard decision must be viewed as another example of the Court's rejecting congressional policy in favor of its own.

Perhaps because of these apparent inconsistencies between the policies of the Act and the decision in Fibreboard, the Court was very careful there in limiting the reach of its decision. As Justice Stewart noted in his National Woodwork dissent, ${ }^{00}$ the Fibreboard Court did not intend to establish any broad principle. On the contrary, it said: $:^{100}$

The Company's decision to contract out the maintenance work did not alter the Company's basic operation. The maintenance work still had to be performed in the plant.... [T] he Company merely replaced existing employees with those of an independent contractor to do the same work under similar conditions of employment. Therefore, to require the employer to bargain about the matter would not significantly abridge his freedom to manage the business.

Justice Stewart's comment on the use of Fibreboard as a basis for the decision in National Woodwork seems definitive to me. He said:101

An employer's decision as to the products he wishes to buy presents entirely different issues. That decision has traditionally been regarded as one within management's discretion, and Fibreboard does not indicate that it is a mandatory subject of collective bargaining, much less a permissible basis for a product boycott made illegal by federal labor law.

\section{ConcLuston}

The majority opinion in National Woodwork is so strained and artificial that it cannot be regarded as a seriously intended piece of statutory analysis. In the circumstances, one must "look to the equities"; one must search for the policy considerations which animated the majority. These are not hard to find. Justice Brennan speaks much of "onrushing technological change," of the "significant and difficult problems" posed by such change, and of his expectation that any congressional intent to preclude union resistance to such change "be preceded by extensive congressional

\footnotetext{
ss The language of $\S 8(\mathrm{~b})(2)$ is very broad: "It shall be an unfair labor practice for a labor organization ... to cause or to attempt to cause an employer to discriminate against an employee in violation of subsection (a) (3) ..."

${ }^{90} 386$ U.S. at $66_{2}-63$.

100379 U.S. at 213.

${ }^{101} 386$ U.S. at $66_{3}$.
} 
study and debate, and consideration of voluminous economic, scientific, and statistical data."102 A similar preoccupation is evident in the opinion of Justice Harlan, whose concurrence was vital to the majority. In his brief concurring opinion, Justice Harlan made room to say: ${ }^{103}$

Especially at a time when Congress is continuing to explore methods for meeting the economic problems increasingly arising in this technological age from scientific advances, this Court should not take such a step until Congress has made unmistakably clear that it wishes wholly to exclude collective bargaining as one avenue of approach to solutions in this elusive aspect of our economy.

Anyone with a minimum understanding of conditions in the construction industry must have difficulty believing that such fears of technological displacement had a rightful, or even sensible, role to play in the decision in National Woodwork. One of the most profound problems of the industry is posed by the paucity of technological development which has occurred there, and references to "onrushing technological change" are incongruous, if not downright funny. Equally significant, the construction industry has been suffering a severe labor shortage, especially in the skilled trades, for many years. Speaking recently with carpenters in Chicago, I heard everywhere that they have more work than they can handle. Many told me that they stop working when they have earned $\$ 400$ in a week because they wish to keep their taxes down. Contractors who try to get too many hours from their carpenters only lose them to those who are willing to accept fewer hours of work.

I have dwelt at length on the National Woodwork case because of the attitude it reveals and because of the problems which that attitude poses for any legislative program designed to limit the capacity of the construction unions to rig costs and prices. The various provisions of the National Labor Relations Act which I have reviewed in this article, take them all in all, constitute a strong, clear, and coherent design for the confinement of monopolistic union practices. Notwithstanding that fact, the administration of the law by the National Labor Relations Board generally, and by the Supreme Court all too frequently, has left unions with substantially the control over labor supply and costs that they had before the Taft-Hartley Act was passed. Possibly, indeed, their control has increased in the years since r947.

Perhaps it is time, then, to abandon the attempt to control the peacefully exerted economic pressures of trade unions. Or perhaps it is time for Congress to take from the Labor Board the virtual monopoly which it has had in administering the National Labor Relations Act, and to permit aggrieved parties to go directly to court for relief. Appropriate modification of the Norris-LaGuardia Act would be needed. It is long overdue.

Ending on an optimistic note, I should like to remind the reader once again of the

${ }^{102}$ Id. at 640 .

${ }^{103}$ Id. at 650 . 
"lineup" in the National Woodwork case. Only a bare majority could be mustered in support of the decision. Four Justices saw with Justice Holmes that "much trouble is made by substituting other phrases assumed to be equivalent, which then are reasoned from as if they were in the Act." Those four Justices were willing to apply Congress's law as it was written, even though the result would have been to limit the socially exploitative activities of trade unions, those favorites who have so often been the objects of the whole Court's tenderest solicitude. There is ground here for the hope, first, that the Court may one day come firmly to the conclusion that it is best all round to leave the basic policy-making to Congress; and second, that the whole Court may one day agree-with Congress, the dissenters in National Woodwork, and the universal opinion of economists-that monopolistic conduct is no more in the general interest when trade unions engage in it than it is when bureaucrats or businessmen are involved. 